\title{
LECTURERS' PERCEPTION TOWARD BASIC READING TEXTBOOK IN STKIP PGRI SUMATERA BARAT
}

\author{
Febby Carmila Rozman ${ }^{1)}$, Sesmiyanti S,.S, M.Pd), Suharni S.S, M.Pd \\ ${ }^{1}$ STKIP PGRI Sumatera Barat, Indonesia \\ ${ }^{2}$ STKIP PGRI Sumatera Barat, Indonesia \\ ${ }^{3}$ STKIP PGRI Sumatera Barat, Indonesia \\ E-mail: $\underline{1 \text { febbycarmila78@gmail.com, }}{ }^{2}$ sesmivanti09@gmail.com, \\ suharnithalib5@gmail.com
}

Submitted: 23-07-2020

Accepted: 21-11-2020

DOI: https://doi.org/10.22202/tus.2020.v6i1.4243

\begin{abstract}
This study aims to describe the lecturers' perception of the Basic Reading textbook used in the Basic Reading Course. This study used a qualitative approach with a total of 2 respondents. The data collection technique used semi-structured interviews with 2 English Education Study Program lecturers at STKIP PGRI Sumatera Barat. The results of this study explained that lecturers' perception toward Basic Reading textbook was based on four main components of the Basic Reading textbook, namely: content, vocabulary and grammar, exercises and activities and as well as the attractiveness and physical make up of the textbook. The lecturers' perception of the content of the textbook was very helpful for students in understanding learning. Regarding vocabulary and grammar in the Basic Reading textbook, according to the lecturer who used the Basic Reading textbook, the used of vocabulary and grammar was easy to understand and in accordance with student abilities. The activities used have an effect on students in implementing character education in the learning process. Exercises also required students to think critically. The attractiveness and physical make up of the textbook showed that the textbook cover and pictures on the textbook were very attractive to students because the textbook components are based on Multimodality. Multimodality is a combination of elements such as visual design, pictures, writing variations, layout, utterance, diagrams and tables and more.
\end{abstract}

Keywords: Basic Reading Textbook, Lecturers'Perception

\section{INTRODUCTION}

Reading is the act of seeing, understanding, and interpreting the contents of reading or writing carried out by the reader to obtain the message and information to be conveyed by the author in the reading mediaWardah (2017) states reading is "a fluent process of readers combining information from a text and their own background knowledge to build meaning and the goal of reading is comprehension". Khruawan \& Dennis state "reading is probably the most 
important skill for the student learning development because students use written texts in searching for information and acquiring new data of knowledge". Nunan (2003), reading is a fluent process of readers combining information from a text and their own background knowledge to build. It means without reading, students cannot improve their understanding of the material; they become less information and also knowledge. Thus, reading is very useful for the students in the learning process

One of the media used in learning and comprehension reading that is a textbook. Definition of textbook is the source of learning. Textbook is one of elements of printed media and source information which is needed by the lectureres. Bojanic \& Topalov (2016) "a textbook is defined as a book that teaches a particular subject and that is used especially in schools and colleges".

Teaching and learning processes can be affected by learning materials especially in the reading classroom. In the reading classroom, learning and understanding a text can be influenced by the format and the medium of the text being read (Rockinson- Szapkiw et. al 2013).

The component of textbook represents textbook visual shape, and content inside. According to Miekley (2005) "there are four components of textbook. (1) Content: is about the subject matter in the textbook which presented. (2) Vocabulary and Grammar: vocabulary on the textbook should a variety of words and Grammar is the grammar rules presented in the textbook. (3) Exercises and Activities: refer to the task that will be given, instruction in the textbook (guideline), and way of communication. (4) The attractiveness of the text and Physical Make-up: the textbook remarked by interesting cover with multimodality, has good visual imagery, appropriate illustration, and besides having interesting multimodality".

Nowadays, STKIP PGRI Sumatera Barat especially in English Study Program has textbook that has been modified in the "Basic Reading" subject. Where the textbook is titled "Basic Reading textbook". Therefore, it is not only the title of the textbook but also the name of the "Basic Reading" subject who 
taught by the lecturer in the English Education Study Program in the academic year 2018/2019.

Basic Reading subject is a subject that examines an ability of students by utilizing science and technology in the field of science. Through this subject, the student is expected to be competent to understand the main concept contained in each paragraph, able to identify the detailed ideas of each paragraph, recognize the pattern of paragraph development, skimming and scanning.

Basic Reading textbook is compiled base on multimodality and the values of character education. Multimodality is "a combination of elements such as pictures, variations of writing, diagrams, tables, utterance and visual design". Design of the textbook consists of pictures, highlight, font color, font style, tables, diagrams, graphics, and others. Norris (2012), Jewitt (2008) defined multimodality as two means of representation and communication, such as still image, gesture, posture, speech, music, writing, or new configurations of the elements. It means multimodality is the combination of several semiotic modes, which is nearly always present in communication.

Character education refers to teaching or giving values to the students. Sesmiyanti et al. (2018) define "Pendidikan karakter merupakan sebuah pengembangan kemampuan yang berkelanjutan dan dinamis dalam diri manusia dalam memahami nilai-nilai positif, aktif dan stabil dalam diri individu”. According to Pala (2011) "Character education is an action which done nationally and intentionally to create ethical, responsible, and caring young people which is actively carried out at school, districts, and states to embed important essence values such as honesty, responsibility, caring, respect, and others.

It can be explained, character education is consisting of positive values and dynamic, sustainability which is useful for students. In addition, the textbook also includes student character education which consists of 18 values: "Keagamaan, Kejujuran, Toleransi, Disiplin, Kerja Keras, Kreativitas, Kemandirian, Demokratis, Rasa Ingin Tahu, Semangat Kebangsaan, Cinta Tanah Air, 
Menghargai Prestasi, Nilai Persahabatan, Cinta Damai, Gemar Membaca, Peduli Lingkungan, Peduli Sosial dan Tanggung Jawab”.

Perception is the act of observing, analyzing, compiling and interpreting information in the form of describing and understanding of something or someone. Lecturers' perception is the point of view, perception and opinion of lecturers on something or anything one of like a textbook. According to Wood (2009) "perception is the process of selecting, organizing and interpreting an object. It can be explained that, perception is the act of observing, analyzing, compiling and interpreting information in the form of describing and understanding something like the Basic Reading textbook.

To find the lecturers' perception toward Basic Reading textbook, it can be seen from the component of textbook.

\section{METHODS}

The research aimed to know lecturers' perception toward the "Basic Reading textbook" in a basic reading subject, the lecturers' of STKIP PGRI Sumatera Barat in academic year 2018/2019. It was located in Gunung Pangilun street, Padang city.

In this research, the researcher used qualitative research as a method to do research. According to Ary (2010), in qualitative research, the researcher tries to see a phenomenon by focusing on the total pictures rather than resolution it down into variables. It means that, qualitative research is a research procedure that focuses on observing and understanding the surrounding phenomena to find the truth that can be explained and substantiated.

Based on the theory above, the researcher chose qualitative research as research design. In this research, the researcher found the lecturers' perception toward Basic Reading textbook based on multimodality and education character in STKIP PGRI Sumatera Barat in academic year 2018/2019.

Respondent is the people who know the information related researcher study. According to Arikunto (2002), "Respondent is a person who can provide 
answer the about variable". In addition, the researcher used purposive sampling to choose respondents. Lufri (2002, p.86), "purposive sampling is a sample that purposed chosen based on the certain need for research". It means the researcher chose the respondents based on purposive sampling to got relevant information and understanding about the topic or set based on criteria, characteristics, and purpose of this research.

In this research, the researcher used semi-structured interview data to take two lecturers who taught and used the Basic Reading subject in English Education Study Program STKIP PGRI Sumatera Barat 2018/2019 academic year in their class as respondents. In addition, the researcher used the semi-structured interview to get perceptions of lecturers toward Basic Reading Textbook in STKIP PGRI Sumatera Barat. The researcher tries to prepare a general guideline for interviewing. Not only that, in conducting interviews the researcher listened carefully and recorded what was found from the informant. In semi-structured interviews, the researcher used 15 items that divided into four parts and were divided into several items as sub-items. There were "(1) Content, (2) Vocabulary and Grammar, (3) Exercises and Activities, (4) Physical Attractiveness and Physical Make-up".

Table 1. Indicator of Lecturers' Perception

\begin{tabular}{cl}
\hline Indicator & \multicolumn{1}{c}{ Sub-Indicator } \\
\hline Content & 1. Textbook contain multimodality \\
& element, there are: \\
& a. Picture \\
& b. Variation of writing \\
& c. Diagram and table \\
d. Utterance & 2. Character education values \\
1. Grammar rules & 2. Texts consist of a variety of \\
& vocabulary
\end{tabular}


Exercises and Activities

The attractiveness of the Text and

Physical Make-up
3. Increase character education knowledge

1. Exercises effect on character education

2. Demanding critical thinking

3. Exercises facilitate to understand the reading text

4. Additional vocabulary facilitates to understand the reading text

1. The textbook has an interesting cover

2. The textbook has an interesting picture

3. The textbook provides enjoy reading

Source: Miekley (2005)

In analysis of the data, According to Ary (2010), "there are three steps in analyzing the data such as (1) organizing and familiarizing, (2) coding and reducing, and (3) interpreting and representing of data based on the approach of research".

\section{FINDING AND DISCUSSION}

The findings had been concluded from the data whichwere analyzed from four items: Content, Vocabulary and Grammar, Exercises and Activities, and the attractiveness and Physical Make-up. First was content, the content had two subitems which was multimodality and character education values. Multimodality consisted of four items such as picture, a variation of writing, diagram and table and utterance. The picture answers showed that the picture was helpful. In the basic reading textbook there were 25 pictures. To variation of writing was related to the font style which was to attract students to read the basic reading textbook. 
In the basic reading textbook, there were 3 types of font styles namely Times New Roman, Comic Sans MS and Calibri. Diagram and table in the basic reading textbook there were two types of diagrams namely lines and bar charts. The line diagram was only one while the bar chart was three in the textbook. While there were 10 tables in the basic reading textbook. The lecturers' perceptions of utterance indicated that first; two respondents said that it was quite understandable for students. Although only a few values are entered because not all character education values were available. However, if it was one or two or several of these values it could be affected student character education, for example, on page 16 in basic reading textbook.

Second, vocabulary and grammar, the sub-items of vocabulary and grammar were grammatical rules; texts consisted of a variety of vocabulary and increased character education knowledge. Two respondents said the grammatically in basic reading textboo is easy to understand.. In vocabulary, two respondents answered that the vocabulary was easy to understand because it used simple vocabulary. This sub-item was related to the use of vocabulary containing the knowledge of character education, the results of the study showed that two respondents said that the used of vocabulary provided knowledge about character education.

Third was exercises and activities, there were three sub-items exercises effected on character education were demanding critical thinking; exercises facilitate to understand the reading text; and additional vocabulary facilitates to understand the reading text. Exercises affected character education, answer showed that exercises gave a positive effected on character education because the practiced of exercises the values of character and student education was applied in the learning process.

The last item was the attractiveness of the text and physical make-up, there were three sub-items: the textbook had an interesting cover; the textbook had an interesting picture; and the textbook provided enjoy reading. Discussing interesting cover, the respondent 1 answered the cover was not interesting and the 
respondent 2 answered that cover in the basic reading textbook was interesting. The reason for the respondent B said that interesting because the color and picture of the textbook on the cover were by following the subject topic of basic reading. Next, to interesting picture sub-items, based on collected data, the respondent 1 said reading text on the basic reading text was not interesting because it needed to be edited again and might be needed the editor to editing. The respondent 2 that pictures on the basic reading text was interesting and attractive, the reason was that it helped explain the text and picture had variety. Last, the textbook provided enjoy reading, two respondents said that attractiveness of the textbook was already good because there were pictures and easy language word which was a help to student easy to understand.

The researcher found the lecturers' perceptions of the textbook showed that a Basic Reading textbook helped students understand the text in learning Basic Reading subject. Not only that, the textbook matched the level of students ability. The textbook also provided advantages and helped lecturers who taught the Basic Reading subject in the teaching-learning process so that the learning process was not rigid and boring.

However, the two lecturers also gave some suggestions regarding their perceptions of the textbook so that the textbook needed to be developed and edited again to make it more interesting to read students, for example, the pictures and utterance in the textbook needed to add more. Not only that, the textbook should be equipped with answer keys to make it easier for lecturers to assess students exercises so that errors did not occur and misunderstanding. This textbook was also highly recommended to include the source of pictures taken. It can be said that the textbook was suitable for the needs of students and lecturers of the English Education Study Program and can be applied to other students every semester in studying Basic Reading subject.

Whereas, the research finding related to this study was proposed by finding made by Diniah (2013) with title is "Teachers' Perceptions towards The Use of English Textbook in EFL Classrooms (A Descriptive Study of EFL 
Teachers at One Islamic Senior High School in Cirebon)" showed that 3 features covered on teachers' perceptions about the textbook: "(1) textbook appropriateness with students' need, (2) textbook suitability with teachers, and (3) syllabus and examination".

First, relational to the suitability of English textbooks to the needs of learners, the teachers are assured that the textbooks used are interesting to learners. On the other hand, two respondents agree that the textbook is suitable for use in teaching basic reading subject. Second, linked to the suitability of the English textbooks with the needed of the teachers, the textbooks used to require little or no time-consuming instruction and the textbooks were suitable for and preferred by fellow teachers. For some other material, the two teachers did not demand much time to draw up the preparation for teaching and to comprehend the clues provided in the textbooks. Three, associated with the textbook suitability with syllabus and examination, some teachers gave information that the textbooks had been suggested or recognized by the experts. However, some teachers also considered weaknesses in the textbooks used in terms of language level difficulty.

Generally, some teachers felt positively towards the English textbooks in used. Furthermore, English textbooks were available additional materials like tapes and visuals. Not only that, the textbooks had no answer keys and teachingaids on describing/applying methods and additional tasks.

Overall, the researcher found that teachers and lecturers' perceptions of the use of the two English textbooks were equally beneficial for lecturers, and teachers in delivering learning material because the textbook contains descriptions of the course included learning outcomes and learning materials Not only that, the textbooks also helped lecturers or teachers in assessing and evaluating exercises and activities undertaken by students. For, the students could increase students' interest in reading.

\section{CONCLUSION}


Lecturers' perception toward basic reading textbook in STKIP PGRI Sumatera Barat conducted well in this research which the respondent was English Education Study Program lecturer who used the Basic Reading textbook in their class in academic year 2018/2019 of STKIP PGRI Sumatera Barat. After the researcher did data analysis above, it could be said that the purpose of the research to know how is lecturers' perception toward basic reading textbook was already achieved. The second respondent's perception of basic reading texbook showed that basic reading textbook helped students understand the text in learning the basic reading subject. Not only that, the textbook matched students levels.

This statement was supported by the data that all of the answered toward basic reading textbook helped students and the textbook had interesting in its attractiveness. The findings had been concluded from the data which was analyzed from four items: Content; Vocabulary and Grammar; Exercises and Activities; and Attractiveness and Physical Make-up.The textbook based on multimodality and character education are seen based on the textbook component which is divided into four items and each item is divided into sub-items. Based on semi-structured interview data, the results of the research show that the lecturers' perception toward basic reading textbook indicates that textbook helps students and advantages lecturers in the teaching-learning process, but some improvements are needed in the textbook to make it more interesting and efficient in their use in the process learning.

Not only that, two respondents agree that the textbook is suitable for use in teaching Basic Reading subject because the textbook contains descriptions of the course included learning outcomes and learning materials. In conclusion, the respondents believe that the textbook provides great support for the teachinglearning process.

\section{REFERENCES}

Arikunto, S. (2002). Prosedur Penelitian: Suatu Pendekatan Praktek. https://doi.org/2006

Ary, D., Jacobs, L. C., \& S. (2010). Introduction to Research in Education 
(Eighth).

Retrieved

from http://www.modares.ac.ir/uploads/Agr.Oth.Lib.12.pdf

Bojanic, Radic \& Topalov, J. (2016). Textbooks in the EFL classroom: Defining, assessing and analyzing. University of Novi Sad, 3, 137-153. https://doi.org/10.5937/zrffp46-12094

Diniah, S. N. (2013). Teachers' Perceptions Towards the Use of English Textbook in Efl Classrooms. Journal of English and Education, 1(2), 72-81. Retrieved from http://ejournal.upi.edu/index.php/L-E/article/view/587/444

Jewitt, C. (2008). Multimodality and Literacy in School Classrooms. Review of Research in Education, 32(1), 241-267. https://doi.org/10.3102/0091732x07310586

Khruawan, P., \& Dennis, N. K 2017 A Study Of English Reading Comprehension Using Content-Based Instruction Approach. International Journal of Research - GRANTHAALAYAH 5 1368-375

Lufri, L. (2002). Kiat Memahami Metodologi dan Melakukan Penelitian (1st ed.). Padang: UNP Press.

Miekley, J. (2005). ESL Textbook Evaluation Checklist. The Reading Matrix, $5(2)$.

Norris. S. 2012. Multimodality in Practice: Investigating Theory-in-Practicethrough-Methodology. United Kingdom: Routledge

Nunan, David. 2003. Practical English Language Teaching.1st Ed New York: McGraw-Hill Companies.

Pala, A. 2011. The Need For Character Education. International Journal of Social Sciences And Humanity Studies, 3210

Rockinson- Szapkiw, A. J., Courduff, J., Carter, K., \& Bennett, D 2013 Electronic versus traditional print textbooks: A comparison study on the influence of university students' learning. Computers \& Education 63 259-266

Sesmiyanti, Rindilla Antika, Y. (2018). Persepsi Mahasiswa Tentang Pendidikan Karakter pada Buku Teks Reading di Perguruan Tinggi Swasta. Pendidikan Bahasa Dan Sastra, https://doi.org/https://doi.org/10.22437/pena.v7i2.5289

Wardah, W. (2017). Metacognitive Reading Strategy Enhancing English Reading 
Comprehension. Fakultas Tarbiyah \& Ilmu Keguruan, 8(1). https://doi.org/10.24260/at-turats.v8i1.107

Wood, M. (2009). Students' Perception on Teacher'S Communication Style on Student'S Motivation in Learning English. https://doi.org/10.22202/tus.2017.v3i2.2627 